\title{
Uso de tecnologias de realidade virtual imersiva para treino e certificação de competências
}

\section{Using immersive virtual reality technologies for training and certification of competencies}

M. Melo

EDITORIAL | EDITORIAL

Dada a evolução significativa das tecnologias de Realidade Virtual, estas tornaram-se ferramentas robustas para diferentes áreas de aplicação que vão muito para além da área do entretenimento. Uma das áreas onde esta tecnologia se tem destacado é no treino e certificação de competências em contexto profissional.

A competitividade na indústria faz com que as empresas tenham que ser o mais eficientes possíveis e que tenham que adotar estratégias que permitam a otimização de recursos. Uma das áreas onde as tecnologias de realidade virtual podem dar um contributo significativo para promover essa mesma otimização de recursos é na área do treino e formação corporativo. À medida que a indústria se torna mais especializada, é crucial garantir que os seus colaboradores tenham as competências necessárias para cumprir as suas funções. No entanto, o treino de técnicos especializados é um processo por vezes complexo, dispendioso e que requer um período de tempo significativo para garantir que os colaboradores adquiram as competências necessárias para o desempenho das suas funções.

Com a disseminação das tecnologias de realidade virtual, o treino e formação corporativo torna-se cada vez mais comum. Esta abordagem já demonstrou ser vantajosa por diferentes motivos:

- Repetibilidade: é possível executar o ambiente de treino um número ilimitado de vezes, com as variáveis desejadas e em qualquer altura;

- Redução de custos: não é necessário parar as atividades nem o normal funcionamento de uma empresa para executar o treino assim como também não é necessário gastar recursos para fins de treino;

- Segurança: o treino decorre em ambiente realista e controlado, sendo que ambientes de treino que envolvam riscos para a integridade física dos intervenientes ou de segurança (p. ex. operações em altura, com substâncias perigosas, procedimentos médicos de alta complexidade)

- Personalização: é possível configurar todo o ambiente de treino para ir de encontro com as necessidades formativas da entidade promotora do treino assim como para responder às dificuldades concretas dos formandos. Por exemplo, para um formando pode ser mais importante treinar uma parte de um procedimento em concreto enquanto para outro formando pode ser mais importante apenas treinar todo o procedimento mas com variáveis diferentes à mistura tais como eventos inesperados para verificar até que ponto o formando está preparado para lidar com tais situações; 
- Controlo sobre o treino: o treino pode ser acompanhado em tempo real ou a posteriori pela equipa formadora de forma a analisar a performance do formando. Para além disso, em tempo real, a equipa formadora pode induzir situações no treino para ver a resposta dos formandos e aferir os seus conhecimentos/competências.

Apesar de todas estas vantagens, atualmente, o desenvolvimento de programas de treino baseados em Realidade Virtual ainda apresentam algumas barreiras que impedem a sua adoção de uma forma mais natural, nomeadamente a necessidade de o seu desenvolvimento requerer uma equipa especializada, os custos associados à criação dos mesmos e o tempo associado ao seu desenvolvimento.

Para ultrapassar estas barreiras e democratizar o acesso a programas de treino baseados em realidade virtual, estão a ser propostas ferramentas de autoria que permitem, de uma forma expedita, a construção de cenários de treino virtuais mesmo para pessoas que não sejam especializadas em desenvolvimento tecnológico.

Um passo natural no seguimento do desenvolvimento destas ferramentas de autoria é o de realmente avaliar se os programas de treinos desenvolvidas com as mesmas conferem a transferência de conhecimento e de competências desejadas. O desenvolvimento deste tipo de ferramentas envolve duas grandes linhas de investigação: a componente tecnológica associada à própria ferramenta (p. ex. metáfora de interação, métodos para visualização de dados ou requisitos funcionais e não funcionais) e a componente associada à performance e transferência de conhecimento/competências. Assim, perspetiva-se como uma linha de investigação próspera a criação de ferramentas tecnológicas que permitam avaliação de performance de formandos que sejam submetidos a estes programas de treino virtual.

Posto isto, parece-nos evidente a necessidade de acelerar a produção de conhecimento que permita consolidar este percurso da aplicabilidade tecnológica. Atualmente são poucas as plataformas para a disseminação deste novo conhecimento e as que existem tendem a ser língua inglesa,. Estas revistas tendem a privilegiar os manuscritos que evidenciam resultados estatisticamente significativos e rejeitando aqueles que levantam questões quanto à eficácia das novas propostas. Dada esta realidade a PsychTech reveste-se da maior importância para os pesquisadores que desejam publicar quer sejam resultados favoráveis ou desfavoráveis à aplicabilidade das novas tecnologias. Assim, reforçamos o convite para a submissão de estudos que tenham por objectivo evidenciar a aplicabilidade da realidade virtual aos múltiplos contextos onde é possível potenciar a performance humana. 